\title{
BIRMINGHAM UNIVERSITY RADIOCARBON DATES II
}

\author{
F. W. SHOTTON, D. J. BLUNDELL, and R. E. G. WILLIAMS
}

The University of Birmingham, Birmingham, England

Measurements have continued with the $6 \mathrm{~L}$ counter which has proved reliable at pressures as high as $2.6 \mathrm{~atm}$ and as low as $0.3 \mathrm{~atm}$. It has now been enclosed in a double ring of 27 geiger tubes which has reduced the background count to $10 \mathrm{cpm}$ at $2 \mathrm{~atm}$. So far, we have had no success with the $1.5 \mathrm{~L}$ Oeschger-type proportional counter. Failure to obtain steady readings is probably due to continued outgassing from the teflon insulation. All insulating parts have now been remanufactured from the same source of teflon as was used in the $6 \mathrm{~L}$ counter, and the Oeschger counter is being reassembled.

Results are still given without correction for $\delta \mathrm{C}^{13}$. Errors quoted refer only to the standard deviation calculated from a statistical analysis of count rates and the Libby half-life of $5570 \pm 30 \mathrm{yr}$.

\section{SAMPLE DESCRIPTIONS}

I. BRITISH FULL-GLACIAL

\section{Birm-10. Brandon, Warwickshire}

Twigs in peat from channel at base of gravels of Avon No. 2 Terrace, $1 \mathrm{mi} \mathrm{SW}$ of Brandon $\left(52^{\circ} 22^{\prime} 28^{\prime \prime} \mathrm{N}\right.$ Lat, $1^{\circ} 25^{\prime} 35^{\prime \prime} \mathrm{W}$ Long, grid ref. SP 391753). Dateable stratigraphically and by fauna to Upton Warren Interstadial (Mid-Weichselian). Previous date of 28,200 \pm 500 (NPL-87) refers to same locality (NPL IV, 1966). Subm. by F. W. Shotton.

Birm-27. Brandon, Warwickshire

$30,766+551$

28,816 B.c.

Independent preparation from same sample of twigs as Birm-10.

\section{Birm-24. Four Ashes, Staffordshire}

$$
\begin{gathered}
36,340+770 \\
\text { - } 700 \\
\text { 34,390 в.c. }
\end{gathered}
$$

Plant material (hand sorted) from peat interbedded as lens in gravels underlying red til with Irish Sea erratics $6 \mathrm{mi} \mathrm{N}$ of Wolverhampton $\left(52^{\circ} 40^{\prime} 13^{\prime \prime} \mathrm{N}\right.$ Lat, $2^{\circ} 07^{\prime} 24^{\prime \prime} \mathrm{W}$ Long, grid ref. SJ 916082). Subm. by F. W. Shotton.

\section{Birm-25. Four Ashes, Staffordshire}

Similar sample to Birm-24, from same gravel pit, but from another lens of peaty silt in gravels. Subm. by F. W. Shotton. 


\section{Birm-56. Four Ashes, Staffordshire}

Similar sample to Birm-24 and 25, but from another separated lens of organic sediment in same gravel pit. Subm. by A. V. Morgan.

General Comment: these 3 results indicate Four Ashes gravels may cover large time span in Upton Warren Interstadial (Shotton, 1967).

\section{Birm-46. Fall Bay, Glamorganshire}

(b) $21,815 \pm 629$ 19,865 в.с.

20,846 B.c.
Patella shells from Patella Beach $\left(51^{\circ} 33^{\prime} 54^{\prime \prime}\right.$ N Lat, $4^{\circ} 17^{\prime} 19^{\prime \prime}$ W Long, grid ref. SS 414873) regarded as Interglacial (George, 1932). Date given by radiocarbon falls in glacial period when beach could not have been formed. Determination likely to be in error due to contamination and deposit older than this. (b) is middle $\mathrm{CO}_{2}$ fraction on acid treatment, (c) inner fraction. Subm. by R. E. G. Williams.

II. BRITISH LATE-GLACIAL AND POST-GLACIAL SITES

\section{Birm-8. Church Stretton, Shropshire \\ $8101 \pm 138$ \\ 6151 B.c.}

Carex peat, bottom $7 \mathrm{~cm}$ of peat layer between 52 and $231 \mathrm{~cm}$ depth below silty clay, in sewer trench between Manholes 20 and 21, 1/4 mi NE of Little Stretton $\left(52^{\circ} 30^{\prime} 50^{\prime \prime} \mathrm{N}\right.$ Lat, $2^{\circ} 49^{\prime} 20^{\prime \prime} \mathrm{W}$ Long, grid ref. SO 445924). Overlies strong solifluction gravel; pollen dated VIb. Subm. by P. H. Rowlands.

\section{Birm-9. Church Stretton, Shropshire $\quad 11,048 \pm 376$ \\ 9098 B.C.}

Plant material washed from sample between 40 and $41 \mathrm{ft}$ in gray clay containing bands of black organic clay between $32.5 \mathrm{ft}$ and $44 \mathrm{ft}$

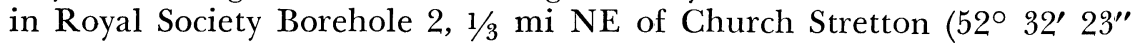
$\mathrm{N}$ Lat, $2^{\circ} 48^{\prime} \mathrm{W}$ Long, grid ref. SO 459939). Underlies strong solifluction gravel; pollen dated II. Subm. by P. H. Rowlands.

\section{Birm-11. Roberthill, Dumfriesshire $\quad 3911 \pm 59$ \\ 1961 B.C.}

Heartwood of tree trunk imbedded in peaty silt on gravel, in bank of River Annan at Roberthill Farm, near Lockerbie $\left(55^{\circ} 06^{\prime} \mathrm{N}\right.$ Lat, $3^{\circ}$ $24^{\prime}$ W Long, grid ref. NY 110797). Measurement on independent sample of material used for Birm-5 (3847 \pm 60$)$. Subm. by G. R. Coope.

\section{Birm-12. Isleham, Cambridgeshire \\ $4201 \pm 60$ \\ 2251 B.c.}

Bog oak with borings of Cerambyx cerdo, part of 60 -ft tree. In peat ca. $1 \mathrm{mi} \mathrm{N}$ of Isleham Parish Church $\left(52^{\circ} 21^{\prime} \cdot 30^{\prime \prime} \mathrm{N}\right.$ Lat, $0^{\circ} 25^{\prime} \mathrm{E}$ Long, 
grid ref. TL 644760$)$. Repeat of Birm-1 $(4001 \pm 66)$ on new material. Subm. by E. A. J. Duffy.

Birm-13. Linwood Moss, Renfrewshire

Peat from basal layer of peat moss at height $26.9 \mathrm{ft}$ O.D., overlying gray silt at Linwood Moss, $3 \mathrm{mi} \mathrm{NW}$ of Paisley $\left(55^{\circ} 52^{\prime} \mathrm{N}\right.$ Lat, $4^{\circ} 29^{\prime}$ W Long, grid ref. NS 439664). Agrees closely with Birm-2 (3572 \pm 64$)$ on separated wood fragments from same peat (Birmingham I, 1967). Subm. by W. W. Bishop.

Birm-19. Heywood, Lancashire

$9065 \pm 247$

7115 B.c.

Sample at base of peat, depth 3.18 to $3.28 \mathrm{~m}$. Garden of 115 Queens Park Rd., Heywood (53 $36^{\prime}$ N Lat, $2^{\circ} 13^{\prime}$ W Long, grid ref. SD 857112). Subm. by D. Lord.

\section{Birm-40. Redkirk Point, Dumfriesshire $\quad 10,898 \pm 127$ \\ 8948 B.c.}

Top 1 in. of peat bed (Peat I), lower of 2 separate beds in silts on foreshore E of Redkirk Point (54 $58^{\prime} 32^{\prime \prime} \mathrm{N}$ Lat, $3^{\circ} 05^{\prime} 30^{\prime \prime} \mathrm{W}$ Long, grid ref. NY 303652). Sample dates abundant insect fauna. Subm. by G. R. Coope.

\section{Birm-41. Redkirk Point, Dumfriesshire $\quad 11,205 \pm 177$ \\ 9255 B.c.}

Bottom 2 in. of same peat bed as Birm-40. Subm. by G. R. Coope.

III. BRITISH ANTARCTIC SURVEY

Samples of wood, seaweed, shell, and whalebone coll. by B. S. John and D. E. Sugden from South Shetland Islands. Whalebone samples have not yet been measured. Samples of recent seaweed and shells show hard water effect by having appreciable apparent ages (Broeker, 1963). This makes determinations of seaweed and shells incorporated in raised beach gravels very difficult to interpret. Dates are therefore given without further comment.

\section{Birm-14. Nelson Island}

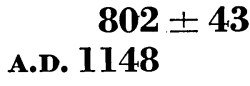

Piece of log part-buried in gravels $23 \mathrm{ft}$ above MSL, $\mathrm{S}$ end of Efacing bay to $S$ of Rip Point $\left(62^{\circ} 15^{\prime} \mathrm{S}\right.$ Lat, $58^{\circ} 59^{\prime} \mathrm{W}$ Long). Expected to date 1 of higher beaches, but low figures cast doubt about validity of specimen as true nonanthropogenic constituent of beach. Wood id. by Forest Products Research Lab. at Princes Risborough as heartwood of Austrocedrus chilensis (Chilean Pine), now growing in narrow zone between Patagonian and Chilean Andes. Modern Austrocedus trees commonly reach $100 \mathrm{yr}$ but rarely as much as 250 . Tree probably not recent, but possibly piece of ship's furniture. Subm. by B. S. John. 
Birm-15. King George Island

Modern seaweed coll. from shoreline as check against similar material in raised beaches, $\mathrm{E}$ of South Spit on $\mathrm{S}$ shore of Marian Cove $\left(62^{\circ}\right.$ 14' S Lat, 58 $48^{\prime}$ W Long). Subm. by B. S. John.

Birm-16. King George Island

$$
1223 \pm 81
$$

A.D. 727

Seaweed from ca. $1 \mathrm{ft}$ depth in raised beach gravel truncating inclined gravel sheets of beach, 16 to $17 \mathrm{ft}$ above MSL; low cliff cut into gravels E of South Spit S shore Marian Cove $\left(62^{\circ} 14^{\prime} \mathrm{S}\right.$ Lat, $58^{\circ} 48^{\prime}$ W Long). Apparently younger than modern seaweed Birm-15. Subm. by B. S. John.

\section{Birm-23. King George Island \\ $7683 \pm 86$ \\ 5733 B.c.}

Seaweed from weathered layer ca. $14 \mathrm{ft}$ above MSL in horizontally bedded gravels, overlain by 4 to $5 \mathrm{ft}$ till rising to $19 \mathrm{ft}$ above MSL, S shore of Potter Cove (62 $14^{\prime} \mathrm{S}$ Lat, $58^{\circ} 41^{\prime}$ W. Long). Subm. by B. S. John.

(a) $850 \pm 145$

\section{Birm-47. King George Island}

(b) $586 \pm 113$

A.D. 1364

Modern bivalve shells (mostly $M y a$ ) from beach on $\mathbf{S}$ shore of Potter Cove $\left(62^{\circ} 14^{\prime} \mathrm{S}\right.$ Lat, $58^{\circ} 41^{\prime} \mathrm{W}$ Long), just above high water mark. Samples from acid treatment of inner (a) and outer (b) shell layers. Subm. by B. S. John.

\section{SPITSBERGEN}

\section{Birm-18. N. Moraine, Balhallfonna, Ny Friesland $9125 \pm 161$ 7175 B.c.}

Probable marine algae in bedded sands and gravels overridden by thrust tills of terminal moraine, $1.5 \mathrm{~km}$ from beach $\left(79^{\circ} 50^{\prime} \mathrm{N}\right.$ Lat, $17^{\circ}$ $50^{\prime}$ E Long). Age possibly overestimated due to hard water effect (Broecker, 1963). Subm. by G. S. Boulton.

\section{Birm-21. S end of Werenskiold Glacier, S.W. Spitsbergen

$$
\delta \mathbf{C}^{14 \% o}=+\mathbf{2 1 . 7} \pm \mathbf{1 1 . 0}
$$

Specimen of moss amongst boulders $\left(77^{\circ} 04^{\prime} 41^{\prime \prime} \mathrm{N}\right.$ Lat, $15^{\circ} 13^{\prime} 23^{\prime \prime}$ E Long) $30 \mathrm{~m}$ above sea level. $\mathrm{N}$ of 1957 glacier termination, $\mathrm{S}$ of 1958 ice surface, and believed to be vegetation uncovered by retreat and representing plants growing before earlier advance of glacier. Determination shows, however, that plants are modern with activity slightly above oxalic acid standard. Subm. by S. Baranowski. 
Birm-37. Head of Sorgfjord, Vestspitsbergen

$6526 \pm 80$

4576 B.C.

Pine wood, piece of drift wood imbedded in top surface of $60 \mathrm{ft}$ raised beach, at head of Sorgfjord, $400 \mathrm{yd}$ from terminus of Dunerbreen. Sample dates part of history of post-glacial sea-level changes in Spitsbergen. Subm. by G. S. Boulton.

v. VOLCANIC DEPOSITS

Birm-35. San Miguel, Azores

$4672 \pm 100$

2722 B.c.

Carbonized wood enclosed in lahar (pyroclastic flow deposit) assoc. with last very large explosive eruption of Fogo Volcano, $5 \mathrm{~km} \mathrm{~N}$ of Villa Franco (37 $45^{\prime} \mathrm{N}$ Lat, $25^{\circ} 25^{\prime} \mathrm{W}$ Long). Subm. by G. P. L. Walker.

\section{Birm-51. Mansion Village, S. Kitts, W. Indies}

$3658 \pm 94$

1708 B.c.

Carbonized wood in ash layer beneath pumice layer, ca. $4 \mathrm{ft}$ below surface in road cutting $S$ of Mansion Village. Pumice layer is from last major eruption of Mt. Misery Volcano (17 $22^{\prime} 50^{\prime \prime} \mathrm{N}$ Lat, $62^{\circ} 45^{\prime} 28^{\prime \prime}$ W Long). Subm. by P. E. Baker (Robson and Tomblin, 1966).

\section{Birm-52. Soufriere Hills, Montserrat, W. Indies $\quad \mathbf{2 3 , 5 6 6} \pm \mathbf{8 8 6}$ 21,616 в.c.}

Charcoal at base of 20-ft-thick pyroclast flow representing last major activity of Soufriere Hills Volcano, $270 \mathrm{ft}$ above MSL, Peat Gut, N side Bethel Village, Montserrat (16 $45^{\circ} \mathrm{N}$ Lat, $62^{\circ} 10^{\prime} \mathrm{W}$ Long). Subm. by P. E. Baker (McGregor, 1938).

\section{ARCHAEOLOGIC SAMPLES}

\section{A. British}

Birm-26. Ryton on Dunsmore, Warwickshire

$$
2701 \pm 41
$$

751 B.c.

Charcoal from pit containing urn of Bronze age $27 \mathrm{in}$. below modern ground surface ca. $1.5 \mathrm{mi} \mathrm{SW}$ Ryton on Dunsmore $\left(52^{\circ} 20^{\prime} 40^{\prime \prime} \mathrm{N}\right.$ Lat, $1^{\circ} 27^{\prime} 15^{\prime \prime} \mathrm{W}$ Long, grid ref. SP. 372725). Dates urn at Late Bronze age and helps determine chronology of Bronze age in English Midlands. Subm. by J. Bateman and V. S. White.

\section{Birm-36. Fladbury, Worcestershire}

$$
1099 \pm 81
$$

\section{A.D. 851}

Charred wood from floor of oven covered by layer of large pieces of burnt daub and then by black earth with pottery pre-1200 A.D. In Fladbury village $\left(52^{\circ} 06^{\prime} 55^{\prime \prime} \mathrm{N}\right.$ Lat, $2^{\circ} 00^{\prime} 28^{\prime \prime} \mathrm{W}$ Long, grid ref SO 995464). Late Saxon date of structure is significant. Subm. by D. P. S. Peacock. 


\section{B. Non-British}

Birm-22. Huenque Valley, Peno, Peru

Carbonized material from hearth in cave ca. $4000 \mathrm{~m}$ above sea level close to road Ilave to Tacna, ca. $40 \mathrm{~km}$ from Ilave $\left(16^{\circ} 40^{\prime} \mathrm{S}\right.$ Lat, $69^{\circ}$ $40^{\prime}$ E Long). Date of occupation later than anticipated. Subm. by P. S. Gelling.

\section{Birm-28. Kintampo, Ghana, Cave KT $1 \quad 2007 \pm 68$}

Four aggregated samples of charcoal from Layers 2 to 5 of Cave KT 1 in Inselberg $\mathrm{N}$ of Kintampo-Tamale $\mathrm{Rd}$. at Milestone $136\left(8^{\circ} 04^{\prime} \mathrm{N}\right.$ Lat, $1^{\circ} 44^{\prime} \mathrm{W}$ Long). Figure dates upper levels of cave earth which contain debris of quern factory. Subm. by P. A. Rahtz.

Birm-30. Kintampo, Ghana, Cave KT 1

$\mathbf{3 3 3 9} \pm \mathbf{3 5}$

1389 B.C.

Three aggregated samples of charcoal from Layers 8 and $8 \mathrm{~b}$ of Cave KT 1 (see Birm-28). Dates lower occupation levels of cave. Subm. by P. A. Rahtz.

\section{Birm-29. Kintampo, Ghana, Cave K $6 \quad 3570 \pm 84$ \\ 1620 B.c.}

Broken husks of fruit (Celtis adolphifriderici), 76 to 77 in. depth in cave floor in ashy layer of test pit. Assoc. with pottery and stone axes $\left(8^{\circ} 01^{\prime} \mathrm{N}\right.$ Lat, $1^{\circ} 45^{\prime} \mathrm{W}$ Long). Husks are almost entirely $\mathrm{CaCO}_{3}$; age was measured on $\mathrm{CH}_{4}$ from acid-generated $\mathrm{CO}_{2}$. There is possibility of "hardwater" error. Subm. by P. A. Rahtz.

\section{Birm-31. Kintampo, Ghana, Cave K $8 \quad 3401 \pm 74$ \\ 1451 B.c.}

Broken husks of fruits (Celtis adolphifriderici) from cave earth of Cave K 8, Buobini $0.5 \mathrm{mi}$ W of Kintampo $\left(8^{\circ} 04^{\prime} \mathrm{N}\right.$ Lat, $1^{\circ} 44^{\prime} 33^{\prime \prime}$ W Long). Dates newly defined Buobini culture (but cf. Birm-29, possibility of overestimate of age due to mineral carbonate). Subm. by P. A. Rahtz.

$$
\begin{aligned}
& 3659 \pm 66 \\
& 1709 \text { в.C. } \\
& 3642 \pm 36 \\
& 1692 \text { B.C. }
\end{aligned}
$$$$
\text { Birm-34. Ledro, Trento, Italy }
$$

Wooden beam found in waterlogged layer of Bronze age settlement at Molina di Ledro, Trento Province, (Battaglia, 1943). Two figures are independent determinations on gas from same specimen. Date is important in settling disputed age of Early Bronze age Polada culture. Subm. by L. H. Barfield. 


\section{Birm-20. Tarkhan II Linen}

(a) $4224 \pm 97$ 2274 B.c.

(b) $4206 \pm 68$ 2256 B.c.

Sample provided by British Mus. is same material dated $4265 \pm$ 80 (UCLA-739) $4200 \pm 90$ (A-569), $4310 \pm 90$ (NPL-5), and $4150 \pm$ 110 (Burleigh, pers. commun., by British Mus.) (a) represents 1000 mins of counting at $1 \mathrm{~atm}$ and (b) 1000 mins at $2 \mathrm{~atm}$. Determination to check calibration of Birmingham Lab.

\section{Birm-42. Piazzo del Cuoma, Pisa, Italy $\quad 3877 \pm 116$ 1927 B.C.}

Wood in "Upper Sand," Sample 8 of Borehole 110, testing stratigraphical sequence around Leaning Tower, $9.4 \mathrm{~m}$ below ground level and $6.4 \mathrm{~m}$ below sea level. Subm. by A. W. Skempton.

\section{Birm-54. Lake Katwe, Uganda}

$1208 \pm 24$

\section{A.D. 742}

Wood from mud layer $7 \mathrm{ft}$ deep in pit $3600 \mathrm{ft}$ from SW edge of Lake Katwe (Sample 4), ( $0^{\circ} 08^{\prime}$ S Lat, $29^{\circ} 53^{\prime}$ E Long, U.T.M. grid ref. RK 1885). One of series to test sedimentation rate. Subm. by W. H. Morton, Geol. Survey, Uganda.

\section{REFERENCES}

Date lists:

$\begin{array}{ll}\text { Arizona VI } & \text { Haynes, Damon, and Grey, 1966 } \\ \text { Birmingham I } & \text { Shotton, Blundell, and Williams, 1967 } \\ \text { NPL IV } & \text { Callow, Baker, and Hassall, 1966 } \\ \text { UCLA IV } & \text { Berger, Fergusson, and Libby, 1965 }\end{array}$

Battaglia, R., 1943, La Palafitta del Lago di Ledro: Mem. del. Mus. di Storia Nat. della Venezia Tridentina VII.

Berger, R., Fergusson, G. J., and Libby, W. F., 1965, UCLA radiocarbon dates IV: Radiocarbon, v. 7, p. 336-371.

Broecker, W. S., 1963, Radiocarbon ages of Antarctic materials: Polar Record, v. 11, no. 73 , p. 472.

Callow, W. J., Baker, M. J., and Hassall, G. I., 1966, National Physical Laboratory measurements IV: Radiocarbon, v. 8, p. 340-347.

George, T. N., 1932, The Quaternary Beaches of Gower: Proc. Geol. Assoc., v. 43, p. 292.

Haynes, C. V., Jr., Damon, P. E., and Grey, D. C., 1966, Arizona radiocarbon dates VI: Radiocarbon, v. 8 , p. 1-21.

McGregor, A. G., 1938, The Royal Society expedition to Montserrat, B.W.I..: Royal Soc. (London) Philos. Trans., Ser. B, v. 299, p. 1-90.

Robson, G. R. and Tomblin, J. F., 1966, Cat. of the active volcanoes of the world including solfatara fields: Int. Assoc. Volcan., pt. 20, West Indies, p. 5-10.

Shotton, F. W., 1967, Age of the Irish Sea Glaciation of the Midlands: Nature, v. 215 , no. 5108 , p. 1366 .

Shotton, F. W., Blundell, D. J., and Williams, R. E. G., 1967, Birmingham University radiocarbon dates I: Radiocarbon, v. 9, p. 35-38. 